NBER WORKING PAPER SERIES

HEALTH STATUS, HEALTH CARE AND INEQUALITY:

CANADA VS. THE U.S.

June E. O'Neill

Dave M. O'Neill

Working Paper 13429

http://www.nber.org/papers/w13429

\author{
NATIONAL BUREAU OF ECONOMIC RESEARCH \\ 1050 Massachusetts Avenue \\ Cambridge, MA 02138 \\ September 2007
}

This paper was presented at the NBER Frontiers in Health Policy Research Conference, June, 2007. We acknowledge the excellent research assistance of Mei Liao and financial support from the Achelis Foundation and the Weismann Foundation and appreciate the helpful comments of conference participants. The views expressed herein are those of the author(s) and do not necessarily reflect the views of the National Bureau of Economic Research.

(C) 2007 by June E. O'Neill and Dave M. O'Neill. All rights reserved. Short sections of text, not to exceed two paragraphs, may be quoted without explicit permission provided that full credit, including $\odot$ notice, is given to the source. 
Health Status, Health Care and Inequality: Canada vs. the U.S.

June E. O'Neill and Dave M. O'Neill

NBER Working Paper No. 13429

September 2007

JEL No. I1,I11,I12,I18

\begin{abstract}
$\underline{\text { ABSTRACT }}$
Does Canada's publicly funded, single payer health care system deliver better health outcomes and distribute health resources more equitably than the multi-payer heavily private U.S. system? We show that the efficacy of health care systems cannot be usefully evaluated by comparisons of infant mortality and life expectancy. We analyze several alternative measures of health status using JCUSH (The Joint Canada/U.S. Survey of Health) and other surveys. We find a somewhat higher incidence of chronic health conditions in the U.S. than in Canada but somewhat greater U.S. access to treatment for these conditions. Moreover, a significantly higher percentage of U.S. women and men are screened for major forms of cancer. Although health status, measured in various ways is similar in both countries, mortality/incidence ratios for various cancers tend to be higher in Canada. The need to ration resources in Canada, where care is delivered "free", ultimately leads to long waits. In the U.S., costs are more often a source of unmet needs. We also find that Canada has no more abolished the tendency for health status to improve with income than have other countries. Indeed, the health-income gradient is slightly steeper in Canada than it is in the U.S.
\end{abstract}

June E. O'Neill

Baruch College

Dept. of Eco/Fin

17 Lexington Ave.

New York, NY 10010

and NBER

june_oneill@baruch.cuny.edu

Dave M. O'Neill

Baruch College

oneillrsd@aol.com 


\section{Health Status, Health Care and Inequality: Canada vs. the U.S.}

The ongoing debate over how to cover the uninsured has generated interest and support for a nationalized single payer system as an alternative to our mainly private multi-payer system. ${ }^{1}$ The Canadian single payer system is often upheld as an example of the improvements in health outcomes, savings in costs, and more equitable distribution of resources that could be achieved with a system change. The U.S. health care system is often critiqued by noting that health expenditures in the U.S. are the highest among the OECD countries---twice as high on a per capita basis as Canada's. Yet, as measured by two popular indicators of health status - infant mortality and life expectancy ---the U.S. lags behind Canada and many other OECD countries. However, both infant mortality and life expectancy are poor measures of the efficacy of a health care system because they are influenced by many factors that are unrelated to the quality and accessibility of medical care.

In this paper we focus on three questions: (1) What does the evidence show regarding differences in health status that can be attributed to the two systems?; (2) How does access to needed health care resources compare between the two countries?; and (3) Is inequality in access to resources different in the two countries? In other words, what do the data show about differences in the health/income gradient between the two countries?

In this paper we address these issues using a recent data set from the Joint Canada/ U.S. Survey of Health (JCUSH). The survey has the unique feature of being a single survey, designed and conducted jointly by Statistics Canada and the U.S. National Center for Health Statistics. Representative samples of U.S. and Canadian residents were asked the same set of questions under similar conditions. The survey provides information on a wide array of issues related to health status, access to health resources and personal demographic, behavioral and economic characteristics.

We supplement our findings from JCUSH with analysis of data from other Canadian and U.S. surveys and other national and international sources.

\footnotetext{
${ }^{1}$ For example, Physicians for A National Health Program, an organization of 14,000 members, strongly advocates conversion to a single payer system.
} 
Briefly, our findings are: No significant differences are evident in the four health status indicators available in the JCUSH data; A somewhat greater incidence of chronic health conditions in the U.S. combined with evidence of greater access to health treatments in the U.S.; greater access in the U.S. to important health care resources and no evidence that the income/health gradient is any different between the U.S. and Canada. Finally, on two questions asked about satisfaction with health services and the ranking of the quality of services recently received, more U.S. residents than Canadians answered fully satisfied and excellent.

We start by reviewing background information on the Canadian system. We then examine traditional measures of a nation's health status: life expectancy and mortality before turning to our analysis of health status differences as shown in JCUSH and other surveys. Resources are bound to affect the quality of care and we briefly compare those in Canada and the U.S. Finally we analyze and compare the effect of income on health status in the two countries.

\section{Background on the Canadian Health System}

Since the late 1960s Canada essentially has had a universal health insurance system covering all services provided by physicians and hospitals. To implement universal coverage the federal and provincial governments took over full funding of both hospital and physician services, setting physician fees and hospital budgets. During the 70's physicians, dissatisfied with the official fee amounts, chose to work outside the system and bill patients at higher amounts. But with the passage of the Canadian Health Act of 1984 Canada outlawed extra billing and became a rigid one-tier system which restricted the provision of any "core” services outside the public's so-called "Medicare" system (Irvine, Ferguson and Cackett).

All care is "free" for insured services - those provided by physicians and hospitals. No premiums, deductibles or co-payments are imposed. (Other services such as dental care and prescription drugs must be paid for either through private insurance or out-ofpocket.) When no one is faced with any charge for services, demand is unrestrained and costs surge. During the 90's the federal government cut back the block amounts given to 
the provinces. It is not surprising that shortages developed and explicit rationing became widespread in Canada. ${ }^{2}$

The shortages and queues that resulted became an increasingly sore subject in Canada. The condition for shortages was enhanced because of the provision in the 1984 Act that decreed that any service that the single payer provides, no matter how much in short supply it may be, cannot be privately insured or produced and sold in Canada. Relief came, however, in 2005 when the 1984 Act was struck down as unconstitutional by Canada’s highest court \{Chaoulli v.Quebec (Attorney General), 2005, IS.C.R. 791, 2005 SCC 35\}. A slim 4/3 majority ruled that the government's argument-that allowing a private sector, would undermine their public system—was not supported by the actual experience of other countries (U.K., France and Germany) that had converted from single payer to dual systems.

Some legal experts have concluded that the Chaoulli decision does not require the government to give up its single payer system as long as it keeps waiting times within a reasonable amount, especially for serious cases. But in practice the decision seems to have led to a large increase in private facilities providing core services, with the expectation that the government will not bring them to court given the Chaoulli decision (Krauss, NY Times, 2006). To many observers Canada now is on its way to becoming a two-tier system.

Private-sector spending on health has been growing faster than public spending and now makes up a little more than $30 \%$ of total health expenditures. Canada spends far less of its GDP on health expenditures than the United States (10.4\%in 2005 compared to 16\%in the U.S.). Public funding of health expenditures has grown in the U.S. and now pays for more than $45 \%$ of the nation's health bill.

\section{Two Traditional Measures of System Performance and Their Drawbacks}

Life expectancy and infant mortality are the two measures most frequently cited as evidence of the superiority of the Canadian system. of medical care. Current data show that life expectancy at birth in the U.S. is 80.1 years for women and 74.8 years for men, more than 2 years below Canada's levels of 82.4 and 77.4 (Table1). Similarly, infant

\footnotetext{
${ }^{2}$ Provincial governments develop fee schedules and set up physician funding pools. If a pool goes over budget, "claw-back clauses" are enforced to ratchet down pay or doctors may be urged to close for a few days. Hospitals meet cost cutting by closing down hospital beds. See MacKenzie,1999.
} 
mortality in the U.S. is 6.8 (deaths per 1000 live births) and 5.3 in Canada. But as noted above, both of these measures are influenced by many factors that are unrelated to the quality and accessibility of medical care. We discuss them briefly in turn.

It is well established that infant mortality is strongly linked to low birth weight and to preterm births. Preterm births accounted for $36.5 \%$ of all infant deaths in the U.S. in 2004 according to the Center for Disease Control (CDC, 1999-2004). The preterm-related infant mortality rate is particularly high for non-Hispanic black mothers---3.5 times higher than the rate for non-Hispanic white mothers. This obviously is an important factor underlying the huge gap in infant mortality between blacks and whites in the U.S. as shown in table 1.

It has long been known that babies born to teenage mothers are at particularly high risk of infant mortality due to their high prevalence of low birth weight. The teenage birth rate in the U.S., despite a substantial decline since the early 1990s is the highest among comparable countries (United Nations Statistics Division, 2004). In 2004, the teenage birth rate was 41.4 (per 1000 girls 15-19) and that was 2.8 times the rate in Canada and 7 times the rates in Japan and Sweden (which have the lowest infant mortality rates). Within the U.S. the infant mortality rate, the pre-term related infant mortality rate and the teen birth rate are considerably higher for blacks than for whites. ${ }^{3}$ The relatively high percentage of births to teenage mothers in the U.S. and the accompanying high rates of infant deaths due to pre-term and low-birth weight births surely contribute to the higher U.S. infant mortality rate.

Evidence that these factors can explain the infant mortality differential between the U.S. and Canada is shown in Table 2 which is based on results of a study by Kramer et. al. investigating the decline in infant mortality in the U.S. Canada and other countries. As a by-product, the findings provide data on the distribution of births by birth weight in Canada and the U.S. and the birth-weight specific infant mortality rates in each country. The data for 1997 (1995-97 in Canada) are displayed in Table 2 and show that the U.S. has disproportionately more low weight births than Canada. For example in the U.S. $1.4 \%$ of births were under 1500 grams compared to $0.9 \%$ in Canada. However, within

\footnotetext{
${ }^{3}$ In 2004 the infant mortality rate of black non-Hispanic mothers was 13.6 compared to 5.7 for white nonHispanic mothers. About 35\% was preterm- related for blacks; 32\% for whites. The teenage birth rate in the same year was 60 for blacks and 27 for white non-Hispanics.
} 
birth weight specific categories, mortality rates in the U.S. were generally the same as in Canada. In fact, our calculations indicate that if in Canada the distribution of births by birth weight was the same as in the U.S. their infant mortality rate would rise to 7.06 from the observed level of 5.5. Similarly if births in the U.S. had the same distribution by birth-weight as Canadian births, the U.S. infant mortality rate would have been 5.401 instead of 6.85 .

Clearly a multitude of behaviors unrelated to the health care system such as substance abuse, smoking and obesity as well as low education and cultural factors are related to the low birth weight and preterm births that underlie the infant death syndrome (Corman and Grossman, 1985; 1987; Joyce, Racine, McCalla and Wehbeh, 1995; Joyce and Grossman, 1990; Kestner, Joyce and Wehbeh,, 1996). It has proven difficult for public efforts to improve birth outcomes for low socioeconomic groups simply by reducing financial barriers to prenatal care. Improvement in access to health care for low income women through extension of Medicaid seems to have increased prenatal care but failed to reduce the gap in birth outcomes for poor and non-poor women (Dubay, Joyce, Kaestner and Dubay 2001; Currie and Gruber,1996).

Life expectancy shares similar problems as a measure of a country's quality of health care. It is influenced by infant mortality and at older ages and does not delineate between causes of death susceptible to improved medical treatment ad those that are not (deaths from homicide, auto and other accidents). As shown in Table 3, the U.S. leads the advanced countries in obesity. The percent of the female population in the U.S. that is obese is $33.2 \%$ and in Canada it is $19.0 \%$, and similar differentials prevail for the men. It is noteworthy that in Japan the percent of women who are obese is only 3.2\% (men 2.8\%) and Japan also has the greatest longevity. Clearly the large differential between the U.S. and Canada in obesity accounts for some of their differential in mortality and therefore in life expectancy.

Table 4 shows the differences between Canada and the U.S. in the causes of mortality at different age groups. Although the overall mortality rate is higher in the U.S. at all age groups, the importance non-disease related factors (accidents and homicides) is much greater in the U.S. For men accidents and homicides account for $84 \%$ of the gap in mortality rates at age group 20-24. This percentage declines as age increases, but still 
accounts for close to $30 \%$ of the gap at ages $40-44$. At older ages diseases of the heart are the primary causes of the gap. Although the health system can surely play a role, diseases of the heart are also influenced by factors like obesity, which contributes to high blood pressue, diabetes and other diseases.

\section{Other Measures of Health Status and of Resource Availability}

Our analysis of the well known differentials in life expectancy and infant mortality suggests that the differentials in these measures of health status (especially infant mortality) are not likely to be due to health care system differences between Canada and the U.S. We continue our search for evidence of health outcome differentials that can be attributed to the effectiveness of the two systems. We utilize the various measures of health status available in the JCUSH data as well as in other data sources and we examine other indicators of health care services and resources including the waiting times that have been sore spots in characterizing the Canadian system. The indicators chosen include some of those on the OECD's list of useful indicators for measuring system performance.

JCUSH--the Joint Canada/U.S. Survey of Health—was conducted by means of a telephone survey of residents of the U.S. and Canada aged 18 and older living in private dwellings with telephones. The data were collected during the period November 2002March 2003. Interviewers were trained and the survey was administered in English or Spanish to Americans and in English or French to Canadians as need dictated. The final samples include 3,505 Canadians and 5,183 from the U.S. The US samples were stratified by four regions; the Canadian sample by province. Appendix Table A-1 presents the weighted characteristics of the samples for the two countries used in our analysis.

\section{Alternative Health Status Measures}

Table 5 presents a subjective measure of health status that reflects how individuals rate their overall level of health: poor, fair, good, very good and excellent. This is a widely used measure in health research. But it has two drawbacks for the purpose of comparing the relative efficacy of our two health care systems. One is that it is so broad that it surely reflects many factors other than the efficacy of the health care systems. The other is the 
purely subjective nature of the measure. If the frame of reference influencing the concept of good health differs significantly between two countries it may not useful for answering the question whether one population is healthier than the other. Given that Canada and the U.S. are so close geographically and similar culturally in many ways, this may not be a serious problem. In Table 5 we control for two obvious non-system factors that affect health status-age and race. We also present results estimated from other major surveys of health status in the U.S. and Canada which ask the same question.

The results in Table 5 show either no difference in self-perceived health status or a slight indication of a higher percentage reporting excellent health in the U.S. It is reassuring for the validity of the measure that the older population (ages 65years or more) indicates poorer health in both countries. Results from the other surveys -The National Health Interview Survey(NHIS) and the U.S. Medical Expenditures Panel Survey (MEPS) for the U.S. and the Canadian Community Health Survey (CCHS) for Canada are based on much larger sample than the JCUSH data but show very similar results. These results are obviously not hard evidence that the quality of health care is the same in both countries. More detailed and objective measures of health status must be sought.

Table 6 shows three more indicators of health status (all from JCUSH) that are more objective, but remain subject to many factors other than the efficacy of the health care system. The first measure is the individual's score on the Health Utility Index (HUI). The index, based on the Comprehensive Health Status Measurement System(CHSMS) developed at McMaster University, provides a description of an individual's overall functional health based on eight attributes - vision, hearing, speech, mobility (ability to get around), dexterity of hands and fingers, memory and thinking, emotion, and pain and discomfort. The HUI maps the responses into a scale ranging from negative to 1 (where one means perfect health and negative means worse than death). The HUI sequence of questions was administered to all respondents. The second measure refers to the probability of a major depression in the last year based on a set of questions from the Composite International Diagnostic Interview. The last measure is a response to a question whether the respondent has pain that prevents some or most activities.

The comparisons are shown by age and by race. We use the 65+ age break here and throughout the paper because Medicare provides near universal coverage for that age 
group in the U.S., a factor that might change the relative standing of the countries when compared with results for the younger respondents. We show separate results for whites because non-whites are a larger proportion of the population in the U.S.(for 18-64 group $26 \%$ for US and 19\% for Canada); the composition of the non-white group differs by country - predominantly black in the U.S., but Asian in Canada; and racial differences in health outcomes may differ in the two countries.

For the 18-64 year old age group the results show no significant difference on any of the three indicators especially when the comparison is restricted to whites only. The depression index shows a 0.7 percentage point higher probability of depression Differences are minimal for the other indicators. For the older group the differentials between the U.S. and Canada are about the same as for the younger group. But again we note that in comparison with the younger group the older group shows generally weaker health based on the lower HUI and the higher level of reported pain. The older group also shows a lower level of the probability of depression, which is consistent with general psychiatric data that shows that serious mental disorders are more likely to begin at younger ages with recovery accompanying the aging process.

What can be concluded from this type of data? Seemingly the results suggest that if there is a difference in health status it is not large enough to be noticed by the population or to generate differences in the other three indices that are based on more objective criteria. But the results still cannot tell us whether the health systems are equally efficient.

Table 7A (for the younger population) and 7B (for those ages 65+) contain measures related to the incidence of significant chronic health conditions. Such health status indicators are more specific and are less subjective than overall self reported health status. However, like our more subjective measures, they are still influenced by socioeconomic status, life styles and genetic factors. But they are likely to be responsive to improvement through medical treatment. Table 7A shows that for the first five conditions, Canada has a lower incidence in all categories, but the difference is rather small except for high blood pressure. For the last three conditions that relate to the functioning of the heart, the two countries are nearly the same. The tables also show the percentage of those currently with the condition who are receiving treatment for it. On 
this indicator of access to care the U.S. generally performs better with respect to the treatment of all conditions except that of asthma.

As expected, the incidence of the specified conditions is greater for the over 65 group than for the younger group. The percent getting treatment also increases. For the older group, the U.S. shows significantly higher incidences of heart disease and coronary heart disease and significantly lower incidence of angina, while for those under 65 there is little difference between the countries in the much lower incidence figures for these three conditions. However, due to sample size limitations the results for the older group are less reliable.

In sum the message of Tables 7A and 7B is that the incidence of important chronic conditions is somewhat higher in the U.S., especially for those that are not heart related, while the utilization of treatment for these conditions is somewhat greater in the U.S. We next turn to JCUSH and other data sources to investigate the availability of certain key health care services in the two countries.

Resource Availability

Table 8 shows utilization rates of preventive care services by Canadians and Americans. We look at mammography, PAP Smears and colonoscopy or sigmoidoscopy (CorS) for women, and the incidence of PSA testing and (CorS) for men in the two countries for relevant age groups. The table shows first, for each age group, the percent of women who at the time of the survey said they had ever had a mammogram or PAP smear. The table then distributes this same sub-group by how recently they had their last mammogram or PAP smear, but using the total number of women in the age group in the denominator. (The percent having the procedure more than 5 years ago is not shown.) The table clearly shows that these two significant cancer screening health services are used significantly less in Canada than in the U.S., especially when the percentages who said they had been screened quite recently are compared. Given the significance of these treatments for preventing mortality due to breast and cervical cancer these differentials have to loom large in any comparison between the two countries. The difference in PSA testing (for prostate cancer) is also very large as is the difference in (CorS). Again given the importance of these two screening devices (especially colonoscopies for colon 
cancer) these have to be considered as potentially affecting the health outcomes produced by Canada.

Table 9 looks at the mental health status of the populations of the two countries, focusing on depression and the type of professional help obtained to treat it. The index used to measure depression was constructed from a series of questions relating to classical symptoms of depression—anxiety attacks; inability to sleep; inability to concentrate on job or other normal aspects of life. The index was used to assign to each individual a probability of having an episode of serious depression in the coming year. About $87 \%$ of respondents in the 18-64 age group were assigned a zero probability. We looked at the roughly 10 percent of the age group with a $90 \%$ probability of a major depressive episode in the coming year. The percent with a high probability of a major depression was somewhat higher in the U.S. than in Canada (9.7\% versus 9\%). Of that group we calculated the percent who consulted a health professional in the past 12 months and then for those who received professional help we tabulated the type of professional consulted. The type of professional consulted is of interest. The percentage that was treated by a psychiatrist is significantly higher in the U.S. (26\% in the U.S. versus $17 \%$ in Canada). However, the institutionalized population is absent from the survey. Differences in policy concerning deinstitutionalization may influence these results.

Table 10 presents data on the availability of Magnetic Resonance Imaging (MRI) and Computed Tomography (CT) Scanners in Canada and the U.S. and also provides comparison with other OECD countries. The gap between the U.S. and Canada is very large-32.0 per million vs 11.3 per million for CTs and 27.0 per million vs 5.5 per million for MRIs. Note that it is difficult to make accurate comparisons across countries in some cases because of differences in the location of the equipment-hospitals or specialized facilities or exclusions of private facilities. But for the U.S. and Canada this is not a problem. (See the notes to the table.) Again, as with the differentials in screening, the huge gap in equipment has the potential to create differentials in health outcomes. On the other hand, if such expensive equipment is inefficiently used in the 
U.S. it could contribute to the higher expenditures in the U.S. but have little effect on health outcomes as some critics suggest. ${ }^{4}$

\section{Waiting Times-How Long and How Important To Health Outcomes?}

One useful side effect of the Chaoulli decision has been an increase in the collection of data on waiting time for various medical services in Canada. Waiting times are an emotionally charged issue in Canada and evidence on the number and lengths of significant waiting times have the potential of moving the country closer to a "two-tier" system.

How widespread and how long are actual waiting times in Canada? And how do these waiting times compare with the U.S.? Table 11 shows how times vary in Canada by type of source. The shortest waiting time shown was collected by Statistics Canada (but refers to two procedures combined). The longest estimates are those of the Fraser Institute. The medium estimates are those of the OECD. Although the methodology appears to be the same, one cannot be sure that they are so in all respects. For example, there could be differences in the voluntary component of scheduling which are not taken into account.

The issue of waiting time has not been prominent in the U.S. and is not routinely surveyed by the U.S. statistical agencies. The JCUSH data do not measure lengths of waiting spells but do present information on the significance of waiting to individuals in the two countries. The question is addressed as part of an inquiry about whether the respondent experienced unmet medical needs and if so, what the reason was for the unmet need. Among those ages 18-64, a somewhat higher percentage of Americans (14.4\%) than of Canadians (11.3\%) reported experiencing one or more unmet health care needs in the year prior to the survey (Table 12). Among older people the percentages reporting unmet needs are about the same in the two countries. Those with an unmet need were then asked the reason for the unmet need ---had to wait too long or service not available; cost ( i.e. could not afford service); or a reason other than those two. As Table 12 shows, the wait too long/service not available reason dominates among the Canadians

\footnotetext{
${ }^{4}$ In their study of the British health care system Aaron and Schwartz address the relatively low level of spending by the British on imaging machines, raising the question, "Sensible Savings or Foolish Frugality?” (pp.89).
} 
who had an unmet need, while for U.S. residents cost was the major factor and wait too long was relatively minor. Other reasons were about equally important in both countries.

Table 13 provides some direct information about the length of the wait for services in Canada and in the U.S. For knee-replacement surgery the study cited in shows a median waiting time of 12 weeks in Canada versus 5 weeks in the U.S. (These figures include both the time it took to see a specialist and the time elapsed between the specialist's decision on surgery and the actual performance of the surgery.) The other comparison in Table 13 is based on a special survey of individuals funded by the Commonwealth Institute and carried out by the Canadian Institute for Health Information. (These figures give separately the times to go from an internist to a specialist and from the specialist's surgery decision to the actual surgery). The waiting times are significantly greater in Canada. $^{5}$

Clearly “all the instruments agree”, waiting times are significantly longer in Canada than in the U.S.. But does the extra waiting time have an important effect on well being? Using the JCUSH data we cross-classified individuals in each country who reported having an unmet need by the reason for it and whether they reported suffering significant pain during the year (see Table 6 above). We found that among those who gave "wait too long or not available” as reasons, 33\% of the Canadians said they had pain that limits their activities while $22 \%$ of the much smaller group of Americans who indicated that waiting time was a reason for an unmet need reported pain. Among those who gave "cost" as the reason for the unmet need, 29\% of Americans reported pain-37\% of the smaller group of Canadians.

We also examined the effect of unmet needs on the Health Utility Measure (HUI) of health status and found that in Canada unmet needs reduced the HUI by 0.097 (compared to a mean of 0.898 ) when the individual cited waiting as a reason for unmet need (holding other variables constant in a multiple regression model; see Appendix Table2). The effect is much smaller and not significant for Americans.

\footnotetext{
${ }^{5}$ Note that the Fraser Institute data in Table 11 for joint replacement surgery (for which knee replacement is a major component) indicate a much longer waiting time (30 weeks) than the study cited in Table 13. These differences could be attributed to differences in sampling as well as differences in concept. But both indicate long waits.
} 


\section{Evidence of Differential System Effectiveness}

Based on our analysis of JCUSH and of other large health interview surveys in Canada and the U.S. we find significant differences between the two countries in the use

of early detection testing (mammograms, pap tests, PSA tests and colonoscopies) and in the availability of medical imaging machines used for early detection (MRIs and Ct Scans). The US is a much greater user of testing and has many more units of imaging machines per capita. If these procedures and machines are impacting on health outcomes we should observe it in data on mortality rates for those who have cancer. Ideally on would want to know the results of broadly applicable studies of survival rates conducted under the same circumstances in both countries, but those are difficult to find. Table 14 provides a very rough approximation of a cancer outcomes study.

Table 14 shows relevant data collected by cancer institutes in Canada and the U.S. on mortality rates and incidence rates for five types of cancer that could be affected by early detection tests as well as by treatment efficacy. Note that the relevant comparison is between the ratios of the mortality rate to the incidence rate in the two countries. The lower this ratio, the lower is the death rate for those who have the disease (roughly speaking). Comparing the mortality rate with the incidence rate is important because high mortality taken alone may simply be the result of a high incidence of the cancer due to environmental, cultural or other such factors. As shown in Table 14, among women the age adjusted cancer incidence rate is higher in the United States than in Canada for all of the types of cancer shown and the mortality rates are somewhat higher in three of the four cancers. The ratio of mortality to incidence is somewhat lower in the U.S. for all cancers together and for three out of the four cancers shown (cervical cancer being the exception). Among men the story is similar, but the ratio is lower in the U.S. for all cancers shown. Thus in terms of the detection and treatment of cancer, the performance of the U.S would appear to be somewhat better than Canada's.

\section{Evidence on the Difference in the Income/Health Gradient}

We turn now to evidence on the claim that in Canada the relation between favorable health outcomes and income is minimal or is much less strong than in the U.S. In other words we investigate whether the income/health gradient is steeper in the U.S. than in Canada. One of the benefits anticipated from a single payer system is a more equitable 
distribution of health resources and health outcomes than would occur in a system where access partly depends on ability to pay.

Although numerous studies have examined the relation between income and health, not many have related inequality in income of individuals to inequality in their health status within a given country. Some studies have looked broadly at the relation between health and income-- historically; and across and within countries (Cutler, Deaton and Lleras-Muney. Many studies simply look at variation in mean income across areas (countries, states) and relate it to observed measures of health status (Marmot 2002). Other across-location studies relate measures of inequality of income (variation across areas) to variation in the average level of health across areas (Ross et al., 2000).

Our interest, however, is in the correlation across individuals in their personal income and their personal health status, and in the comparison of this relationship in Canada and the U.S. The data demands of such a study are ordinarily difficult to meet. because of the difficulty of assembling data for different countries with similar measures of both income and health status. Data on the personal incomes of individuals and households are collected in both Canada and the U.S, as are some measures of health status (typically self reported health status). But the data on income are both measured and published in different formats making unbiased estimates in both countries difficult to execute. The main empirical problem in comparing gradients in the U.S. and Canada is that both the mean and relative variation of income is significantly greater in the U.S. And the crude techniques for measuring personal income variation have biased most existing estimates toward finding a steeper gradient in the U.S.

We utilize mainly JCUSH, which offers the best opportunity for measuring incomes in each country in the same way and thus derive unbiased estimates of the gradient in each country. Studies comparing gradients between countries have finessed the problem of non-comparable income distribution data by using a crude measure of income inequality (Decker and Remler, 2004). We use the JCUSH data to illustrate the bias in the previous studies.

Tables 15-A and 15-B present evidence on the size of the income/health gradient in the U.S. and Canada, separately by age and for whites and the total population. For the younger group it is clear that except for one comparison (among whites for the poor or 
fair measure of health status) there is a steeper gradient in the U.S. between the average of the health indicator for all those below the median vs all those above the median. For example the average percent poor or fair drops by 9.8 percentage points for all Canadians while in the US the corresponding drop is 11.8 percentage points. Similarly the average percent reporting very good or excellent health rises by 18.8 percentage points in Canada and by 23.7 percentage points in the U.S. However, for the older group the results are not so clear cut. In more than half the comparisons the gradients are steeper in Canada.

But all of the above and below the median comparisons in these tables are biased toward finding a steeper slope in the U.S. This bias is revealed when one uses the relatively detailed income data in JCUSH to compute the mean income of those individuals with incomes above and below the median. (The means of those above and below the median are displayed in the tables.) Note that the ratio of mean income of those above the median to the mean income of those below median income in the U.S. is significantly greater for both the all person comparisons and the white only comparisons. For all persons the Canadian ratio is 3.27 and the U.S. ratio is 3.54, while for the white only comparison the Canadian ratio is 3.21 and the U.S. is 3.40. This means that the relative variance of income across persons is much greater in the U.S., and this would generate a larger spread in the measures of health status even if the gradient were the same in both countries. By simply using above and below the median in each country we are in effect forcing a_steeper gradient on the U.S. data.

Fortunately, the JCUSH data enable us to make comparisons using a continuous income variable that assigns a value to each individual. Thus the greater relative spread in the U.S. income data can be measured with some accuracy. The rate of change can be estimated as the partial regression coefficient of the income variable in separate multiple regression equations for Canada and the U.S. (using the health measure as the dependent variable) and the results for the two countries can be compared. The larger the coefficient (in absolute value), the steeper will be the gradient. Tables 16 and 17 show the results of our analysis. With JCUSH we were able to do two analyses, one using the Health Utility Index (HUI) to measure health status (Table 16) and one using self reported poor/fair (Table 17). 
Table 16 shows the partial effect of income on the health utility index in three multiple regression models that hold different numbers of other variables constant. Income, as Cutler, Deaton and Lleras-Muney (2005) note, itself is likely to be affected by health. It is also correlated with other variables that affect health status such as education and chronic conditions. We don't expect to resolve these difficult problems of cause and effect. But we do the regression in stages so that changes in the effect of income on health can be observed when different variables are included in the regression. Model 1 contains controls for demographic variables and education. Model II adds variables that measure health risks such as underweight, obesity, smoking currently or formerly, and a series of chronic conditions. Model III adds health access variables - unmet needs due to waiting, cost or other reasons, whether has a regular doctor and whether needed medicine but couldn't afford it. Means of all the variables and full results for all the independent variables in the model III version With HUI as the dependent variable are provided in the Appendix.

Note that among the 18-64 year olds, the gradient in all three HUI regression models is actually steeper in Canada than in the U.S. (Table 16). And the same result holds when we use fair/poor to measure health status (Table 17). For this measure of health status the Canadian coefficients are quite a bit steeper than those in the U.S.. The results are less consistent for the older age group. In the HUI regression results the gradient is weaker in Canada than in the U.S. and is not statistically significant. But the results with fair/poor as the health status measure again show steeper gradients for the older group in Canada. ${ }^{6}$

Perhaps it should not be surprising to find that the gradient is alive and well in Canada despite the presence of a single payer system. It is difficult for any society to change traits that are health risks and that are usually strongly correlated with income. Nor does free access to medical care guarantee equal ability to navigate and use the health care system.

\section{Consumer Satisfaction}

\footnotetext{
${ }^{6}$ Income for retired individuals, however, can be unreliable because income from assets and imputed income from owned homes are a larger component of income but are not adequately reflected in the income measure.
} 
Table shows tabulations from two JCUSH questions, one dealing with how one rates the quality of care received and the other with overall satisfaction with health care services received in the past year. Perhaps surprisingly, U.S. respondents quite significantly gave higher ratings to the quality of care received and were more satisfied with health care services received than were the Canadians.

\section{Concluding Comments}

It is commonly supposed that a publicly funded single payer health care system will deliver better health outcomes, and distribute health resources more fairly than a multipayer system with a large private component. Based on our analysis of health care measures in Canada and the U.S. we find a somewhat greater incidence of chronic health conditions in the U.S. combined with evidence of greater access to health treatments for these conditions. Health status is similar in both countries. But Canada has no more abolished the tendency for health status to improve with income than have other countries. Indeed, the health-income gradient is more prominent in Canada than it is in the U.S. The need to ration when care is delivered "free" ultimately leads to long waits or unavailable services and to unmet needs. In the U.S. costs are more often a source of unmet needs. But costs may be more easily overcome than the absence of services. When asked about satisfaction with health services and the ranking of the quality of services recently received, more U.S. residents than Canadians respond that they are fully satisfied and rank quality of care as excellent.

One important issue that we do not address concerns the large differential in per capita health care expenditures which are about twice as large in the U.S. Is the U.S. getting sufficient additional benefits to justify these greater expenditures and where should we cut back if cutbacks must be made? Alternatively, what would Canada have to spend to increase their technical capital and specialized medical personnel to match American levels or to eliminate the longer waiting times? And would it be worthwhile to them to do so? To answer these questions more research is needed along the lines of the recent study by Henry Aaron and William Schwartz (2005) that examines the British system in depth and in comparison to the U.S. system. 


\section{References}

Aaron, Henry J. and Schwartz, W.B. 2005. Can We Say NO? The Challenge of Rationing Health Care, The Brookings Institution, Washington, DC

Canadian Institute for Health Information, CIHI report shows increases in MRI and CT scanners, up more than 75\% in the last decade, 2004.

Canadian Institute for Health Information, Health care spending to reach \$142 billion this year, 2005.

Corman, H., Joyce, T., and Grossman, M. 1987. "Birth Outcome Production Functions in the U.S." Journal of Human Resources. 22: 339-360.

Corman, Hope, and Grossman, M. 1985. “Determinants of Neonatal Mortality Rates in the U.S.: A Reduced Form Model.” Journal of Health Economics, 4 (3): 213-236.

Currie, J, and J. Gruber. 1996. "Saving Babies: The Efficacy and Cost of Recent Expansions of Medicaid Eligibility for Pregnant Women." Journal of Political Economy 104 (6): 1263-96.

Cutler, David, A. Deaton and A. Lleras-Muney, “The Determinants of Mortality”, Harvard University and Princeton University, December 2005.

Decker, Sandra L and Remler, D. K 2004. “How Much Might Universal Health Insurance Reduce Socioeconomic Disparities in Health? A Comparison of the US and Canada.” Applied Health Economics and Health Policy, 3 (4): 205-216.

Dubay, L., Joyce, T., Kaestner, R. and G. Kenney. 2001. “Changes in Prenatal Care Timing and Low Birth Weight by Race and Socioeconomic Status: Implications for the Medicaid Expansions for Pregnant Women.” Health Services Research. 36 (2): 373-398. 
Joyce, T., Racine, A., McCalla, S., and Wehbeh, H. 1995. "The Impact of Prenatal Exposure to Cocaine on Newborn Costs and Length of Stay." Health Services Research 30: 341-358.

Joyce, T. 1994. "Self Selection, Prenatal Care and Birthweight among Blacks, Whites, and Hispanics in New York City." Journal of Human Resources 29: 762-794.

Joyce, T., and Grossman, M. 1990. "The Dynamic Relationship Between Low Birthweight and Induced Abortion in New York City: An Aggregate Time-Series Analyses." Journal of Health Economics. 9: 273-288.

Kaestner, R., Joyce, T., and Wehbeh, H. 1996. "The Effect of Drug Use on Birth Weight: Measurement Error in Binary Variables." Economic Inquiry 34: 617-629.

Kelley, Edward and Hurst, Jeremy, “Health Care Quality Indicators Project Initial Indicators Report”, OECD HEALTH WORKING PAPERS \# 22, 2006

Kramer, Michael; Barros, Fernando; Demissie, Kitaw; Liu, Shillang; Kiely, John and Joseph, K.S., “Does reducing infant mortality depend on preventing low birthweight? An analysis of tempoortal trends in the Americas”, Pediatric and Perinatal Epidemiology, 19, 445-451, 2005

Krauss, Clifford, “As Canada’s Slow-Motion PublicHealth System Falters, Private Medical Care Is Surging”, News Article, The New York Times, February 26, 2006

MacKenzie, K. Roy, 1999. “Canada: A Kinder, Gentler Health Care System?” Psychiatric Services, 50 (4):489-491.

Marmot, M., “The Influence of Income on Health: Views of an Epidemiologist”, Health Affairs, 21 (2): 31-46 
Nicolucci, Antonio; Greenfield, Sheldon and Mattke, Soeren, "Selecting indicators for the quality of diabetes care at the health systems level in OECD countries" International Journal for Quality in Health Care, September 2006

Organization for Economic Cooperation and Development, OECD Health Data2006: How Does Canada Compare,

Ross, Nancy, et.al., "Relation Between Income Inequality and Mortality in Canada and the United States: Cross-sectional Assessment, Using Census Data and Vital Statistics”, British Medical Journal, 320:898-902, 2000

Schoen, C, et. al., “International Comparison: Effectiveness”, 2004 Commonwealth Fund International Health Policy Survey, The Commonwealth Fund, Dec. 2006

Stanton, Mark W., "The High Concentration of U.S. Health Care Expenditures”, Rockville (MD), Agency for Healthcare Research and Quality, 2005, Research in Action Issue 19, AHRQ Pub. No 06-0060

Statistics Canada, “Access to Health Care Services in Canada”, Canadian Community Health Survey, Health Services Access Subsample, 2003 and 2005

United Nations Statistics Division,’Teen Birth Rates: How Does the United States Compare” Demographic Yearbook 2004, New York, United Nations

World Health Organization, “International Comparison: Effectiveness”, WHO VaccinePreventable Diseases Monitoring System, The Commonwealth Fund, Dec.2006 


\section{Table 1}

Life Expectancy and Infant mortality in Canada, the U.S. and Selected OECD Countries (2003).

\begin{tabular}{|c|c|c|c|c|c|}
\hline & \multicolumn{4}{|c|}{ Life Expectancy } & \multirow{3}{*}{$\begin{array}{c}\text { Infant } \\
\text { Mortality } \\
\text { (per } 1000 \text { live } \\
\text { births) } \\
\end{array}$} \\
\hline & \multicolumn{2}{|c|}{ At birth } & \multicolumn{2}{|c|}{ At 65 years of age } & \\
\hline & Male & Female & Male & Female & \\
\hline U.S & 74.8 & 80.1 & 16.8 & 19.8 & 6.8 \\
\hline White & 75.3 & 80.5 & 16.9 & 19.8 & 5.7 \\
\hline Black & 69.0 & 76.1 & 15.9 & 18.5 & 13.5 \\
\hline Canada & 77.4 & 82.4 & 17.4 & 20.8 & 5.3 \\
\hline Denmark & 75.1 & 79.9 & 15.5 & 18.6 & 4.4 \\
\hline France & 75.9 & 82.9 & $17.1^{1)}$ & $21.4^{1)}$ & 4.0 \\
\hline Germany & 75.7 & 81.4 & 16.1 & 19.6 & 4.2 \\
\hline Italy & 76.8 & 82.5 & $16.6^{1)}$ & $20.6^{1)}$ & 3.9 \\
\hline Japan & 78.4 & 85.3 & 18.0 & 23.0 & 3.0 \\
\hline Korea & 73.9 & 80.8 & 15.1 & 19.0 & $5.3^{1)}$ \\
\hline Luxembourg & 75.0 & 81.0 & 15.5 & 19.0 & 4.9 \\
\hline Sweden & 77.9 & 82.5 & 17.0 & 20.3 & 3.1 \\
\hline U.K & 76.2 & 80.7 & $16.1^{1)}$ & $19.1^{1)}$ & 5.3 \\
\hline
\end{tabular}

${ }^{1)}$ Reported for 2002.

Source: OECD Health Data 2007. CDC-NCHS, National Vital Statistics. 


\section{Table 2}

\section{Birthweight Distributions (in \%) ${ }^{\text {a) }}$ and Birthweight-specific}

Infant Mortality (per 1000 live births) in Canada and the United States

\begin{tabular}{|c|c|c|c|c|}
\hline & \multicolumn{2}{|c|}{$\begin{array}{l}\text { Birthweight } \\
\text { Distributions }\end{array}$} & \multicolumn{2}{|c|}{$\begin{array}{l}\text { Birthweight-specific } \\
\text { Infant Mortality }\end{array}$} \\
\hline & U.S. & Canada & U.S. & Canada \\
\hline & $\begin{array}{c}1997 \\
(n=3,884,329)\end{array}$ & $\begin{array}{c}1995-97 \\
(n=656,553)\end{array}$ & 1997 & 1995-97 \\
\hline \multicolumn{5}{|l|}{$\begin{array}{l}\text { Birthweight } \\
\text { category (g) }\end{array}$} \\
\hline$<1500$ & 1.4 & 0.9 & 247.3 & 262.2 \\
\hline 1500-1999 & 1.5 & 1.1 & 29.3 & 36.6 \\
\hline 2000-2499 & 4.6 & 3.7 & 12.2 & 12.9 \\
\hline 2500-2999 & 16.6 & 15.0 & 4.8 & 4.4 \\
\hline$\geq 3000$ & 75.9 & 78.9 & 2.1 & 2.0 \\
\hline Unknown ${ }^{b)}$ & 0.0 & 0.5 & 187.8 & 33.8 \\
\hline$<2500$ & 7.5 & 5.7 & 60.4 & 58.0 \\
\hline
\end{tabular}

a) \%s for birthweight distribution are of those with known birthweight.

b) $\%$ of total births.

Source: Michael S. Kramer, Fernando C. Barros, Kitaw Demissie, Shiliang Liu, John Kiely and K. S. Joseph. "Does reducing infant mortality depend on preventing low birthweight? An analysis of temporal trends in the Americas." Paediatric and Perinatal Epidemiology 2005, 19:447-448, derived from Table 1 and Table 2. 
Table 3

Prevalence of Obesity ( \% with BMI of 30 or more) in United States, Canada and Selected OECD Countries (2004/2005)

\begin{tabular}{|c|c|c|}
\hline & Male & Female \\
\hline U.S & 31.1 & 33.2 \\
\hline Canada & $17.0^{1)}$ & $19.0^{1)}$ \\
\hline Denmark & $11.0^{1)}$ & $11.8^{1)}$ \\
\hline France & 9.8 & 9.3 \\
\hline Germany & $14.4^{1)}$ & $12.8^{1)}$ \\
\hline Italy & $17.0^{1)}$ & $9.7^{1)}$ \\
\hline Japan & 2.8 & 3.2 \\
\hline Korea & $3.7^{1)}$ & $3.3^{1)}$ \\
\hline Luxembourg & 19.0 & 17.1 \\
\hline Sweden & 9.8 & 9.9 \\
\hline U.K & 22.7 & 23.2 \\
\hline \multicolumn{3}{|c|}{$\begin{array}{l}\text { 1) Countries reporting data for 2005; all others } \\
\text { reported for } 2004 . \\
\text { Note: I he Body Mass Index (BMI) Is based on } \\
\text { weight (kilograms) divided by height } \\
\text { (meters)sauared. } \\
\text { Source: OECD Health Data } 2007 .\end{array}$} \\
\hline
\end{tabular}




\section{Table 4}

Mortality Rates by Age Group in Canada and the United States and Percent of the U.S.-Canada Mortality Gap in Each Age group Due to Accidents/Homicides and to Heart Diseases

\begin{tabular}{|c|c|c|c|c|c|c|c|c|c|c|}
\hline & \multicolumn{5}{|c|}{ Female } & \multicolumn{5}{|c|}{ Male } \\
\hline & \multicolumn{2}{|c|}{$\begin{array}{l}\text { Mortality due to } \\
\text { all causes }\end{array}$} & \multirow{2}{*}{$\begin{array}{c}\text { Gap } \\
(U S-C A)\end{array}$} & \multirow{2}{*}{$\begin{array}{l}\% \text { of Gap } \\
\text { due to } \\
\text { accidents } \\
\text { and } \\
\text { homocides }\end{array}$} & \multirow{2}{*}{$\begin{array}{c}\% \text { of Gap } \\
\text { due to } \\
\text { diseases } \\
\text { of heart }\end{array}$} & \multicolumn{2}{|c|}{$\begin{array}{l}\text { Mortality due } \\
\text { to all causes }\end{array}$} & \multirow{2}{*}{$\begin{array}{c}\text { Gap } \\
\text { (US-CA) }\end{array}$} & \multirow{2}{*}{$\begin{array}{l}\% \text { of Gap } \\
\text { due to } \\
\text { accidents } \\
\text { and } \\
\text { homocides }\end{array}$} & \multirow{2}{*}{$\begin{array}{c}\% \text { of Gap } \\
\text { due to } \\
\text { diseases } \\
\text { of heart }\end{array}$} \\
\hline & US & $C A$ & & & & US & $C A$ & & & \\
\hline \multicolumn{11}{|l|}{ By age } \\
\hline $20-24$ & 47.3 & 32.1 & 15.2 & 64.5 & 3.9 & 138.0 & 82.4 & 55.6 & 84.4 & 4.3 \\
\hline $25-29$ & 54.5 & 33.3 & 21.2 & 51.9 & 10.4 & 135.6 & 79.8 & 55.8 & 74.4 & 7.3 \\
\hline $30-34$ & 72.0 & 43.6 & 28.4 & 32.4 & 13.4 & 143.2 & 89.7 & 53.5 & 60.0 & 13.8 \\
\hline $35-39$ & 109.3 & 66.7 & 42.6 & 32.2 & 20.0 & 193.8 & 120.9 & 72.9 & 42.8 & 17.4 \\
\hline $40-44$ & 174.5 & 97.5 & 77.0 & 23.0 & 18.6 & 289.5 & 172.0 & 117.5 & 27.6 & 23.1 \\
\hline $45-49$ & 262.5 & 172.3 & 90.2 & 18.8 & 28.2 & 444.4 & 269.8 & 174.6 & 19.6 & 27.2 \\
\hline $50-54$ & 372.7 & 273.6 & 99.1 & 13.1 & 38.7 & 657.0 & 428.7 & 228.3 & 12.9 & 30.4 \\
\hline $55-59$ & 562.7 & 424.7 & 138.0 & 6.7 & 38.4 & 917.3 & 678.4 & 238.9 & 6.7 & 38.9 \\
\hline $60-64$ & 893.6 & 683.1 & 210.5 & 4.8 & 40.7 & 1411.0 & 1130.2 & 280.8 & 3.1 & 45.4 \\
\hline $65-69$ & 1381.2 & 1075.6 & 305.6 & 1.6 & 41.6 & 2125.1 & 1766.7 & 358.4 & 4.7 & 49.6 \\
\hline
\end{tabular}

Source: CDC/NCHS, National Vital Statistics System, Report LCWK1; Statistics Canada, Catalogue No. 84F0209, Mortality, Summary List of Causes, 2004. 
Table 5

Self Reported Health Status in Canada and the US: Results from Different Surveys

\begin{tabular}{|c|c|c|c|c|c|c|c|c|c|c|}
\hline & \multicolumn{4}{|c|}{ JCUSH } & \multirow{2}{*}{\multicolumn{2}{|c|}{$\begin{array}{l}\text { Canada } \\
\text { CCHS }\end{array}$}} & \multirow{2}{*}{\multicolumn{2}{|c|}{$\begin{array}{l}\text { U.S. } \\
\text { NHIS }\end{array}$}} & \multirow{2}{*}{\multicolumn{2}{|c|}{$\begin{array}{l}\text { U.S. } \\
\text { MEPS }\end{array}$}} \\
\hline & \multicolumn{2}{|c|}{ All Persons } & \multicolumn{2}{|c|}{ White Only } & & & & & & \\
\hline & Canada & U.S. & Canada & U.S. & All & White & All & White & All & White \\
\hline & \multicolumn{4}{|c|}{ Ages 18-64 } & \multicolumn{4}{|c|}{ Ages 20-64 } & \multicolumn{2}{|c|}{ Ages 18-64 } \\
\hline \multicolumn{11}{|c|}{$\begin{array}{l}\text { Self reported health status } \\
\text { (\% distribution) }\end{array}$} \\
\hline Poor & 2.6 & 3.2 & 2.6 & 2.6 & 2.1 & 2.1 & 2.3 & 2.2 & 2.8 & 2.7 \\
\hline Fair & 6.0 & 8.6 & 6.4 & 5.9 & 7.4 & 7.1 & 7.2 & 6.7 & 8.2 & 7.6 \\
\hline Good & 26.2 & 25.9 & 24.0 & 24.6 & 29.4 & 28.4 & 24.4 & 23.7 & 26.9 & 26.2 \\
\hline Very good & 38.1 & 33.8 & 39.3 & 36.9 & 37.2 & 38.2 & 33.8 & 34.5 & 34.8 & 35.8 \\
\hline \multirow[t]{2}{*}{ Excellent } & 27.0 & 28.6 & 27.7 & 30.0 & 24.0 & 24.3 & 32.3 & 33.0 & 27.4 & 27.8 \\
\hline & \multicolumn{10}{|c|}{ Ages 65+ } \\
\hline \multicolumn{11}{|c|}{$\begin{array}{l}\text { Self reported health status } \\
\text { (\% distribution) }\end{array}$} \\
\hline Poor & 7.9 & 9.5 & 8.1 & 8.5 & 6.8 & 6.5 & 7.3 & 6.6 & 6.8 & 6.5 \\
\hline Fair & 19.4 & 19.4 & 17.7 & 16.7 & 19.9 & 19.1 & 18.3 & 17.2 & 17.0 & 16.0 \\
\hline Good & 37.6 & 30.3 & 36.2 & 30.9 & 36.7 & 36.4 & 35.8 & 36.2 & 33.8 & 33.6 \\
\hline Very good & 27.0 & 25.8 & 29.6 & 27.9 & 25.2 & 26.2 & 26.1 & 27.0 & 28.2 & 28.9 \\
\hline Excellent & 8.0 & 15.0 & 8.4 & 16.0 & 11.5 & 11.8 & 12.6 & 13.0 & 14.2 & 15.0 \\
\hline
\end{tabular}

Source: Joint Canada/United States Survey of Health(JCUSH), Canadian Community Health Survey (CCHS), United States National Health Interview Survey (U.S. NHIS), and United States Medical Expenditure Panel Survey (U.S. MEPS): all in year 2003. 
Table 6

Other Indicators of Health Status in Canada and the U.S.

\begin{tabular}{|c|c|c|c|c|}
\hline & \multicolumn{2}{|c|}{ All Persons } & \multicolumn{2}{|c|}{ White Only } \\
\hline & Canada & U.S. & Canada & U.S. \\
\hline & \multicolumn{4}{|c|}{ Ages 18-64 } \\
\hline $\begin{array}{l}\text { Health Utility Index(HUI) } \\
\text { Mean score }\end{array}$ & 0.898 & 0.883 & 0.897 & 0.892 \\
\hline$\%$ with major depression ${ }^{1)}$ & 9.0 & 9.7 & 9.1 & 9.8 \\
\hline \multirow[t]{2}{*}{$\%$ reported pain that limits activities } & 11.0 & 11.9 & 11.2 & 10.6 \\
\hline & \multicolumn{4}{|c|}{ Ages 65+ } \\
\hline $\begin{array}{l}\text { Health Utility Index(HUI) } \\
\text { Mean score }\end{array}$ & 0.795 & 0.782 & 0.798 & 0.798 \\
\hline$\%$ with major depression ${ }^{1)}$ & 3.6 & 3.7 & 3.9 & 3.2 \\
\hline$\%$ reported pain that limits activities & 20.3 & 20.7 & 20.6 & 18.7 \\
\hline
\end{tabular}

${ }^{1)}$ Major depression refers to those with 90 percent probability of depression. This variable calculates the probability that the respondent would have been diagnosed as having experienced a major depressive episode in the past 12 months, if they had completed the Long-Form Composite International Diagnostic Interview (CIDI). The items used to measure depression are a subset of items from the CIDI that measure major depressive episode (MDE). The short-form of MDE used in the JCUSH was developed to operationalize the diagnosis of MDE.

Source: Joint Canada/United States Survey of Health. 
Table 7-A

Incidence and Treatment Status of Certain Health Conditions in Canada and the U.S., Ages 18-64

\begin{tabular}{|c|c|c|c|c|c|c|c|c|}
\hline & \multicolumn{4}{|c|}{ All Persons } & \multicolumn{4}{|c|}{ White Only } \\
\hline & \multicolumn{2}{|c|}{ Canada } & \multicolumn{2}{|c|}{ U.S. } & \multicolumn{2}{|c|}{ Canada } & \multicolumn{2}{|c|}{ U.S. } \\
\hline & $\begin{array}{c}\% \text { with } \\
\text { condition }\end{array}$ & $\begin{array}{c}\text { \% gets } \\
\text { treatment }\end{array}$ & $\begin{array}{c}\% \text { with } \\
\text { condition }\end{array}$ & $\begin{array}{c}\% \text { gets } \\
\text { treatment }\end{array}$ & $\begin{array}{c}\% \text { with } \\
\text { condition }\end{array}$ & $\begin{array}{c}\% \text { gets } \\
\text { treatment }\end{array}$ & $\begin{array}{c}\% \text { with } \\
\text { condition }\end{array}$ & $\begin{array}{c}\% \text { gets } \\
\text { treatment }\end{array}$ \\
\hline 1 Asthma & 6.6 & 80.3 & 7.8 & 78.8 & 6.9 & 82.7 & 7.7 & 77.6 \\
\hline 2 Arthritis excluding fibromyalgia & 11.6 & $N . A$. & 12.5 & $N . A$. & 12.4 & $N . A$. & 13.1 & $N . A$. \\
\hline 3 High blood pressure & 8.8 & 84.1 & 13.1 & 88.3 & 9.1 & 83.2 & 12.5 & 87.3 \\
\hline 4 Emphysema or related disease & 0.5 & 53.0 & 1.3 & 73.1 & 0.6 & 53.0 & 1.4 & 69.4 \\
\hline 5 Diagnosed with diabetes & 3.2 & --- & 4.9 & --- & 3.1 & --- & 3.8 & --- \\
\hline Takes insulin & --- & 24.6 & --- & 28.8 & --- & 30.6 & -- & 24.7 \\
\hline Takes diabetic pills & --- & 63.4 & --- & 72.0 & --- & 58.4 & --- & 65.2 \\
\hline Takes insulin or pills & --- & 80.3 & --- & 83.9 & --- & 79.9 & --- & 79.9 \\
\hline 6 Heart disease & 2.4 & 67.2 & 2.6 & 69.6 & 2.7 & 69.4 & 2.4 & 73.2 \\
\hline 7 Coronary heart disease & 0.9 & 88.9 & 1.0 & 94.8 & 0.9 & 87.5 & 0.8 & 95.6 \\
\hline 8 Angina & 0.9 & 74.6 & 1.1 & 61.0 & 0.9 & 70.7 & 0.8 & 75.1 \\
\hline
\end{tabular}

Source: Joint Canada/United States Survey of Health. 
Table 7-B

Incidence and Treatment Status of Certain Health Conditions in Canada and the U.S., Ages 65 and Over

\begin{tabular}{|c|c|c|c|c|c|c|c|c|}
\hline & \multicolumn{4}{|c|}{ All Persons } & \multicolumn{4}{|c|}{ White Only } \\
\hline & \multicolumn{2}{|c|}{ Canada } & \multicolumn{2}{|c|}{ U.S. } & \multicolumn{2}{|c|}{ Canada } & \multicolumn{2}{|c|}{ U.S. } \\
\hline & $\begin{array}{c}\% \text { with } \\
\text { condition }\end{array}$ & $\begin{array}{l}\% \text { gets } \\
\text { treatment }\end{array}$ & $\begin{array}{c}\% \text { with } \\
\text { condition }\end{array}$ & $\begin{array}{l}\% \text { gets } \\
\text { treatment }\end{array}$ & $\begin{array}{c}\% \text { with } \\
\text { condition }\end{array}$ & $\begin{array}{l}\% \text { gets } \\
\text { treatment }\end{array}$ & $\begin{array}{c}\% \text { with } \\
\text { condition }\end{array}$ & $\begin{array}{l}\% \text { gets } \\
\text { treatment }\end{array}$ \\
\hline 1 Asthma & 7.1 & 82.5 & 6.6 & 91.6 & 7.1 & 82.8 & 6.2 & 91.7 \\
\hline 2 Arthritis excluding fibromyalgia & 39.4 & N.A. & 46.5 & N.A. & 39.6 & N.A. & 46.2 & N.A. \\
\hline 3 High blood pressure & 40.8 & 95.1 & 45.0 & 97.7 & 40.7 & 94.9 & 42.8 & 97.7 \\
\hline 4 Emphysema or related disease & 3.8 & 64.3 & 5.3 & 73.6 & 3.9 & 65.1 & 5.3 & 71.0 \\
\hline 5 Diagnosed with diabetes & 12.9 & -- & 16.3 & --- & 12.0 & -- & 14.8 & --- \\
\hline Takes insulin & --- & 17.5 & --- & 26.3 & --- & 14.9 & --- & 26.7 \\
\hline Takes diabetic pills & --- & 71.7 & --- & 74.0 & --- & 69.7 & --- & 73.2 \\
\hline Takes insulin or pills & -- & 80.4 & --- & 91.3 & --- & 76.0 & --- & 91.5 \\
\hline 6 Heart disease & 13.7 & 91.4 & 17.7 & 90.8 & 12.9 & 92.3 & 17.0 & 90.2 \\
\hline 7 Coronary heart disease & 4.9 & 90.5 & 6.8 & 96.3 & 5.3 & 90.9 & 6.9 & 95.4 \\
\hline 8 Angina & 10.3 & 73.0 & 5.8 & 77.7 & 10.2 & 74.9 & 5.5 & 77.1 \\
\hline
\end{tabular}

Source: Joint Canada/United States Survey of Health 


\section{Table 8}

Preventive Care: Percentage of Relevant Population Group Screened for Various Types of Cancer

\begin{tabular}{|c|c|c|c|c|}
\hline & \multirow{2}{*}{$\begin{array}{c}\text { Canada } \\
\text { CCHS }\end{array}$} & \multirow{2}{*}{$\begin{array}{c}\text { U.S. } \\
\text { MEPS }\end{array}$} & \multicolumn{2}{|c|}{ JCUSH } \\
\hline & & & Canada & U.S. \\
\hline \multicolumn{5}{|l|}{$\begin{array}{l}\text { Mammogram for breast cancer, } \\
\text { women ages } 40-69\end{array}$} \\
\hline \% Ever had mammogram & 72.3 & 88.6 & 73.6 & 85.8 \\
\hline \multicolumn{5}{|l|}{$\%$ Last had mammogram } \\
\hline Less than 2 years ago & 54.7 & 74.9 & 57.1 & 74.1 \\
\hline 2 to less than 5 years ago & 10.6 & 8.0 & 11.1 & 7.1 \\
\hline \multicolumn{5}{|l|}{$\begin{array}{l}\text { PAP smear for cervical cancer, } \\
\text { women ages } 20-69\end{array}$} \\
\hline$\%$ Ever had PAP test & 88.2 & 96.2 & 89.9 & 96.5 \\
\hline \multicolumn{5}{|l|}{$\%$ Last had a PAP test } \\
\hline Less than 3 years ago & 75.1 & 86.3 & 77.5 & 88.2 \\
\hline 3 to less than 5 years ago & 4.6 & 2.7 & 4.3 & 3.3 \\
\hline \multicolumn{5}{|l|}{$\begin{array}{l}\text { PSA test for prostate cancer, } \\
\text { men ages } 40-69\end{array}$} \\
\hline$\%$ Ever had PSA test & 16.4 & 54.2 & & \\
\hline \multicolumn{5}{|l|}{$\%$ Last had PSA test } \\
\hline Less than 3 years ago & 15.2 & 49.5 & & \\
\hline 3 to less than 5 years ago & 0.7 & 2.2 & & \\
\hline \multicolumn{5}{|c|}{$\begin{array}{l}\text { Colonoscopy/Sigmoidoscopy (CorS) } \\
\text { for colorectal cancers, } \\
\text { men ages } 40-69\end{array}$} \\
\hline \% Ever had CorS & 4.6 & 29.0 & & \\
\hline \multicolumn{5}{|l|}{$\%$ Last had CorS } \\
\hline Less than 2 years ago & 1.9 & 16.7 & & \\
\hline 2 to less than 5 years ago & 1.3 & 7.9 & & \\
\hline \multicolumn{5}{|c|}{$\begin{array}{l}\text { Colonoscopy/Sigmoidoscopy (CorS) } \\
\text { for colorectal cancers, } \\
\text { women ages } 40-69\end{array}$} \\
\hline \% Ever had CorS & 5.4 & 29.8 & & \\
\hline \multicolumn{5}{|l|}{$\%$ Last had CorS } \\
\hline Less than 2 years ago & 2.0 & 16.4 & & \\
\hline 2 to less than 5 years ago & 1.6 & 8.2 & & \\
\hline
\end{tabular}

Source: Joint Canada/United States Survey of Health, 2002-2003; Canadian Community Health Survey (CCHS), 2003; U.S.Medical Expenditure Panel Survey (MEPS), 2003. 
Table 9

Incidence and Type of Treatment of Those With Major Mental Depression, Ages 18-64

\begin{tabular}{|c|c|c|c|c|}
\hline & \multicolumn{2}{|c|}{ All Persons } & \multicolumn{2}{|c|}{ White Only } \\
\hline & Canada & U.S. & Canada & U.S. \\
\hline$\%$ with depression & 9.0 & 9.7 & 9.1 & 9.8 \\
\hline $\begin{array}{l}\% \text { with depression who consulted a } \\
\text { health professional }\end{array}$ & 56.2 & 52.1 & 61.9 & 61.2 \\
\hline \multicolumn{5}{|l|}{ Type of professional (\%) * } \\
\hline Family doctor or gen. practitioner & 67.5 & 56.5 & 67.9 & 57.3 \\
\hline Psychiatrist & 17.4 & 26.1 & 17.8 & 25.4 \\
\hline Psychologist & 26.2 & 18.9 & 27.2 & 16.9 \\
\hline Nurse & 5.0 & 4.8 & 5.2 & 3.3 \\
\hline Social worker or counsellor & 18.5 & 15.0 & 17.9 & 15.2 \\
\hline Other professional & 9.3 & 5.3 & 10.4 & 6.2 \\
\hline
\end{tabular}

* Will not add to $100 \%$ because categories are not mutually exclusive.

Source: Joint Canada/United States Survey of Health. 
Table 10

Number of Computed Tomography (CT) Scanners per Million

Population and Number of Magnetic Resonance Imaging (MRI)

Scanners per Million Population in Selected OECD Countries

\begin{tabular}{lcc}
\hline & $\begin{array}{c}\text { Number of CTs } \\
\text { per Million Population }\end{array}$ & $\begin{array}{c}\text { Number of MRIs } \\
\text { per Million Population }\end{array}$ \\
Country (Year reported): & 92.6 & 35.3 \\
Japan (2002) & 32.0 & 27.0 \\
UNITED STATES (2004) & 31.9 & 9.0 \\
Korea (2003) & 27.2 & 13.5 \\
Austria (2003) & 24.0 & 11.6 \\
Italy (2003) & 18.0 & 14.2 \\
Switzerland (2003) & 17.1 & 2.3 \\
Greece (2002) & 14.5 & 9.1 \\
Denmark (2003) & 14.2 & 7.9 \\
Sweden (1999) & 14.2 & 6.0 \\
Germany (2002) & 14.0 & 12.8 \\
Finland (2003) & 13.0 & 7.3 \\
Spain (2003) & 12.6 & 2.4 \\
Czech Republic (2003) & 12.1 & --- \\
New Zealand (2004) & 11.3 & 5.5 \\
CANADA (2005) & 8.7 & 2.0 \\
Slovak Republic (2003) & 8.4 & 2.8 \\
France (2003) & 7.3 & --- \\
Turkey (2003) & 7.0 & 5.0 \\
UK (2004) & & \\
& &
\end{tabular}

Sources: Canadian Institute for Health Information, Medical Imaging in Canada, 2005, pp. 55-56, derived from Figure 17 and Figure 18.

Notes:

a) In Canada, units located both in hospitals and in free-standing imaging facilities are included. Data is as of January 1, 2005.

b) In Japan, only units located in hospitals and general clinics are counted.

c) In Greece, CT scanners/MRI units from military hospitals and private diagnostic centres are also included.

d) In the UK, raw numbers of CT/MRI units for England and Wales have been increased by the OECD Secretariat to provide an estimate for the UK. The private sector is not included in the data.

e) In the U.S., units located both in hospitals and in non-hospital sites are included. IMV was used as the data source, because it counts the number of CTs, whereas OECD figures are a count of the number of hospitals that report having at least one scanner.

f) In Germany, data on medical technology includes equipment installed in acute care hospitals and in prevention and rehabilitation homes. The table comprises CT units as well as PET units. 
Table 11

\section{Waiting Times in Canada for Non-Emergency Surgery: Estimates from Different Data Sources}

Median Weeks Waiting

\section{Data Source and Procedure: \\ Statistics Canada ${ }^{1}$ \\ Joint Replacement and \\ Cataract Surgery \\ 8 \\ $O E C D^{2}$ \\ Joint Replacement \\ Cataract Surgery \\ Fraser Institute ${ }^{3}$ \\ Joint Replacement \\ Cataract Surgery \\ 12}

\footnotetext{
1 "Access to Health Care Services in Canada", January to December 2005, Statistics Canada.

${ }^{2}$ Siciliani \& Hurst, "Explaining Waiting Times Variations for Elective Surgery across OECD Countries", OECD HEALTH WORKING PAPERS (2003) \#7.

${ }^{3}$ Nadeem Esmail \& Michael Walker, "Waiting Your Turn 16th Edition: Hospital Waiting Lists in Canada", The Fraser Institute, 2006.
}

Note: The data were derived from different underlying populations. Statistics Canada bases its numbers on the responses of individuals to questions about their waiting time experiences. The information is obtained as a by-product of their household survey. The OECD utilizes administrative data collected by various provincial governmental agencies. The Fraser Institute generates its own survey of specialist physicians and asks them to estimate patient waiting time from the date the surgery was scheduled to the date the surgery actually took place. All the estimates shown above also refer to that same period-weeks elapsed between the date scheduled by the specialist and the actual surgery. Information (not shown) is also collected on the waiting time between referral to a specialist and the actual meeting with the specialist. 
Table 12

Percent of Those with Self Reported Unmet Health Need and Reason for Unmet Need

\begin{tabular}{lrrrrrr}
\hline & \multicolumn{2}{c}{ Ages 18-64 } & & \multicolumn{2}{c}{ Ages 65+ } \\
\cline { 2 - 3 } \cline { 5 - 6 } & Canada & U.S. & & Canada & U.S. \\
& 11.3 & 14.4 & & 7.4 & 6.4 \\
\% with unmet need & & & & & \\
Reason for unmet need (\%) : & & & & & \\
Wait too long or not available & 56.3 & 13.2 & & 51.9 & 24.6 \\
Cost & 8.6 & 54.7 & & 2.2 & 35.9 \\
Other reasons & 36.6 & 33.2 & & 45.9 & 42.6 \\
\hline
\end{tabular}

* Categories with reasons are not mutually exclusive and therefore will not add to a hundred.

Source: Joint Canada/United States Survey of Health. 
Table 13

Differences in waiting time to see a specialist or have elective surgery: Canada vs. the U.S. ${ }^{1)}$

\begin{tabular}{|c|c|c|}
\hline & Canada & U.S \\
\hline \multicolumn{3}{|c|}{$\%$ waited more than four weeks to: } \\
\hline Consult a specialist & 57 & 23 \\
\hline Have elective surgery & 82 & 42 \\
\hline $\begin{array}{l}\text { Median waiting time for } \\
\text { knee-replacement surgery } \\
\text { (in weeks) }^{2 \text { ) }}\end{array}$ & 12 & 5 \\
\hline \multicolumn{3}{|c|}{$\begin{array}{l}\text { 1) Waiting for Health care in Canada: What we know and What } \\
\text { We Don't Know, Canadian Institute for Health Information (March, } \\
\text { 2007) in Canada. }\end{array}$} \\
\hline \multicolumn{3}{|c|}{$\begin{array}{l}\text { 2) Peter C. Coyte, et. al, "Waiting Times for Knee-Replacement } \\
\text { Surgery in the United States and Ontario" The New England }\end{array}$} \\
\hline
\end{tabular}


Table 14

Incidence Rates and Mortality Rates of Selected Types of Cancer

Average of 2001-2003

\begin{tabular}{|c|c|c|c|c|c|c|c|c|c|c|c|c|}
\hline & \multicolumn{6}{|c|}{ Female } & \multicolumn{6}{|c|}{ Male } \\
\hline & $\begin{array}{l}\text { Incidence } \\
\text { rates }^{\text {a) }}\end{array}$ & $\begin{array}{c}\text { Mortality } \\
\text { rates }^{\text {a) }}\end{array}$ & $M / I^{b)}$ & $\begin{array}{l}\text { Incidence } \\
\text { rates }^{\text {a) }}\end{array}$ & $\begin{array}{c}\text { Mortality } \\
\text { rates a) }\end{array}$ & $M / I^{b)}$ & $\begin{array}{l}\text { Incidence } \\
\text { rates }^{\text {a) }}\end{array}$ & $\begin{array}{c}\text { Mortality } \\
\text { rates }^{\text {a) }}\end{array}$ & $M / I^{b)}$ & $\begin{array}{l}\text { Incidence } \\
\text { rates }^{\text {a) }}\end{array}$ & $\begin{array}{c}\text { Mortality } \\
\text { rates }^{\text {a) }}\end{array}$ & $M / /^{b)}$ \\
\hline All Cancers & 414.5 & 162.5 & 0.39 & 349.8 & 148.6 & 0.42 & 562.1 & 239.4 & 0.43 & 464.4 & 219.7 & 0.47 \\
\hline Breast & 125.3 & 25.6 & 0.20 & 99.0 & 24.5 & 0.25 & --- & --- & --- & --- & --- & --- \\
\hline Prostate & --- & -- & --- & --- & --- & --- & 162.0 & 27.9 & 0.17 & 124.7 & 25.2 & 0.20 \\
\hline Colorectal & 45.6 & 16.5 & 0.36 & 42.8 & 17.5 & 0.41 & 62.6 & 23.7 & 0.38 & 62.8 & 27.2 & 0.43 \\
\hline Cervix & 8.6 & 2.6 & 0.30 & 7.9 & 2.0 & 0.25 & --- & --- & --- & --- & --- & --- \\
\hline
\end{tabular}

a) Incidence and mortality rates are all age-adjusted.

b) Ratio of mortality rate to incidence rate.

Source: United States Cancer Statistics, National Program of Cancer Registries, Centers for Disease Control; Canadian Cancer Society/national Cancer Institute of Canada. 


\section{Table 15-A}

Income and Self-reported Health Status Differences, Ages 18-64 (US dollars *)

\begin{tabular}{|c|c|c|c|c|}
\hline & $\begin{array}{l}\text { Mean of income } \\
\text { category }(000 \text { 's) }\end{array}$ & $\begin{array}{l}\text { Poor or } \\
\text { fair }\end{array}$ & $\begin{array}{l}\text { Very good or } \\
\text { excellent }\end{array}$ & Excellent \\
\hline \multicolumn{5}{|l|}{ All Canadian } \\
\hline$<$ median & 25.7 & 14.7 & 54.2 & 21.2 \\
\hline$\geq$ median & 81.3 & 4.9 & 73.0 & 30.4 \\
\hline \multicolumn{5}{|l|}{ All US } \\
\hline$<$ median & 28.9 & 17.6 & 50.2 & 21.2 \\
\hline$\geq$ median & 96.7 & 5.8 & 73.9 & 34.5 \\
\hline \multicolumn{5}{|l|}{ White Canadian } \\
\hline$<$ median & 25.9 & 15.6 & 55.9 & 22.4 \\
\hline$\geq$ median & 81.6 & 5.1 & 73.6 & 30.7 \\
\hline \multicolumn{5}{|l|}{ White US } \\
\hline$<$ median & 30.6 & 12.8 & 54.6 & 23.0 \\
\hline$\geq$ median & 98.7 & 5.3 & 75.6 & 34.8 \\
\hline
\end{tabular}

* Canadian dollars converted to US dollars using purchasing power parity.

Source: Joint Canada/United States Survey of Health. 
Table 15-B

Income and Self-reported Health Status Differences, Ages 65 and Over (US dollars *)

\begin{tabular}{|c|c|c|c|c|}
\hline & $\begin{array}{l}\text { Mean of income } \\
\text { category (000's) }\end{array}$ & $\begin{array}{l}\text { Poor or } \\
\text { fair }\end{array}$ & $\begin{array}{l}\text { Very good } \\
\text { or excellent }\end{array}$ & Excellent \\
\hline \multicolumn{5}{|l|}{ All Canadian } \\
\hline$<$ median & 21.9 & 30.9 & 30.2 & 5.8 \\
\hline$\geq$ median & 71.7 & 17.2 & 54.2 & 19.1 \\
\hline \multicolumn{5}{|l|}{ All US } \\
\hline$<$ median & 24.9 & 34.2 & 36.0 & 11.7 \\
\hline$\geq$ median & 88.3 & 15.3 & 57.1 & 23.8 \\
\hline \multicolumn{5}{|l|}{ White Canadian } \\
\hline$<$ median & 22.0 & 29.9 & 33.1 & 6.6 \\
\hline$\geq$ median & 70.7 & 14.8 & 57.5 & 17.1 \\
\hline \multicolumn{5}{|l|}{ White US } \\
\hline$<$ median & 26.0 & 29.8 & 38.1 & 12.5 \\
\hline$\geq$ median & 88.4 & 15.9 & 56.9 & 23.7 \\
\hline
\end{tabular}

* Canadian dollars converted to US dollars using purchasing power parity.

Source: Joint Canada/United States Survey of Health. 
Table 16

Effect of Income on Health Utility Index (HUI), JCUSH

\begin{tabular}{|c|c|c|c|c|c|c|}
\hline \multirow{3}{*}{ Regression model: } & \multicolumn{3}{|c|}{ Canada } & \multicolumn{3}{|c|}{ U.S. } \\
\hline & I & II & III & $\mathbf{I}$ & II & III \\
\hline & $\begin{array}{c}\text { Controls: } \\
\text { Demographic } \\
\text { factors }\end{array}$ & $\begin{array}{l}\text { Adds: } \\
\text { health } \\
\text { risks }\end{array}$ & $\begin{array}{l}\text { Adds: } \\
\text { unmet } \\
\text { needs }\end{array}$ & $\begin{array}{c}\text { Controls: } \\
\text { Demographic } \\
\text { factors }\end{array}$ & $\begin{array}{l}\text { Adds: } \\
\text { health } \\
\text { risks }\end{array}$ & $\begin{array}{l}\text { Adds: } \\
\text { unmet } \\
\text { needs }\end{array}$ \\
\hline & \multicolumn{6}{|c|}{ Ages 18-64 } \\
\hline $\begin{array}{l}\text { Partial effect of income } \\
(000 \text { 's) }\end{array}$ & $0.0009 * * *$ & 0.0006 *** & $0.0005 * * *$ & 0.0008 *** & $0.0005 * * *$ & $0.0004 * * *$ \\
\hline Adj. R-Square & 0.0687 & 0.2396 & 0.2749 & 0.0995 & 0.2818 & 0.3143 \\
\hline $\begin{array}{l}\text { Mean of dependent } \\
\text { variable }\end{array}$ & & 0.8978 & & & 0.8840 & \\
\hline \multirow[t]{2}{*}{ Sample size } & & 2663 & & & 3797 & \\
\hline & \multicolumn{6}{|c|}{ Ages 65+ } \\
\hline $\begin{array}{l}\text { Partial effect of income } \\
(000 \text { 's) }\end{array}$ & 0.0005 & 0.0003 & 0.0003 & $0.0008 * * *$ & $0.0006 * *$ & 0.0005 \\
\hline Adj. R-Square & 0.0677 & 0.2098 & 0.2240 & 0.1165 & 0.2564 & 0.2826 \\
\hline $\begin{array}{l}\text { Mean of dependent } \\
\text { variable }\end{array}$ & \multicolumn{3}{|c|}{0.7961} & \multicolumn{3}{|c|}{0.7830} \\
\hline Sample size & \multicolumn{3}{|c|}{684} & \multicolumn{3}{|c|}{1017} \\
\hline
\end{tabular}

Note: Complete regression results are shown in the Appendix for Model III (mean characteristics and variable coefficients). The demographic variables in Model I include sex, age group, education, whether nonwhite, whether immigrant, whether married and whether lives alone. Model II adds whether obese and other weight related variables, current and former smoking, incidence of various chronic diseases. Model III adds unmet needs and whether has regular doctor. Starred figures denote statistical significance at the following levels: *10\%; ** $5 \%$; ***1\%.

Source: Joint Canada/United States Survey of Health (JCUSH) microdata file. 
Table 17

\section{Effect of Income on Whether Reported Poor/Fair Health Status, JCUSH}

\begin{tabular}{|c|c|c|c|c|c|c|}
\hline \multirow{3}{*}{ Regression model: } & \multicolumn{3}{|c|}{ Canada } & \multicolumn{3}{|c|}{ U.S. } \\
\hline & I & II & III & I & II & III \\
\hline & $\begin{array}{l}\text { Controls: } \\
\text { Demographic } \\
\text { factors }\end{array}$ & $\begin{array}{l}\text { Adds: } \\
\text { health } \\
\text { risks }\end{array}$ & $\begin{array}{l}\text { Adds: } \\
\text { unmet } \\
\text { needs }\end{array}$ & $\begin{array}{l}\text { Controls: } \\
\text { Demographic } \\
\text { factors }\end{array}$ & $\begin{array}{l}\text { Adds: } \\
\text { health } \\
\text { risks }\end{array}$ & $\begin{array}{l}\text { Adds: } \\
\text { unmet } \\
\text { needs }\end{array}$ \\
\hline & \multicolumn{6}{|c|}{ Ages 18-64 } \\
\hline $\begin{array}{l}\text { Partial effect of income } \\
(000 \text { 's) }\end{array}$ & $-0.0013 * * *$ & $-0.0008 * * *$ & $-0.0008 * * *$ & $-0.0009 * \star *$ & $-0.0004 * * *$ & $-0.0003 * *$ \\
\hline Adj. R-Square & 0.0623 & 0.2082 & 0.2203 & 0.0929 & 0.2437 & 0.2589 \\
\hline $\begin{array}{l}\text { Mean of dependent } \\
\text { variable }\end{array}$ & & 0.0854 & & & 0.1163 & \\
\hline \multirow[t]{2}{*}{ Sample size } & & 2710 & & & 3870 & \\
\hline & \multicolumn{6}{|c|}{ Ages 65+ } \\
\hline $\begin{array}{l}\text { Partial effect of income } \\
\text { (000's) }\end{array}$ & $-0.0019 * * *$ & -0.0014 * & -0.0014 ** & $-0.0017 * * *$ & -0.0011 ** & -0.0009 * \\
\hline Adj. R-Square & 0.0432 & 0.2300 & 0.232 & 0.0831 & 0.2328 & 0.2407 \\
\hline $\begin{array}{l}\text { Mean of dependent } \\
\text { variable }\end{array}$ & & 0.2725 & & & 0.2860 & \\
\hline Sample size & & 732 & & & 1090 & \\
\hline
\end{tabular}

Note: The demographic variables in Model I include sex, age group, education, whether nonwhite, whether immigrant, whether married and whether lives alone. Model II adds whether obese and other weight related variables, current and former smoking, incidence of various chronic diseases. Model III adds unmet needs and whether has regular doctor. Starred figures denote statistical significance at the following levels: * $10 \%$; ** $5 \%$; ${ }^{* \star} 1 \%$. (The regression specification is the same as that for the HUI regression detailed in the appendix. Regression results are available from the authors.)

Source: Joint Canada/United States Survey of Health (JCUSH) microdata file. 
Table 18

Quality and Satisfaction with Health Care Services

\begin{tabular}{lrrrrrr}
\hline & \multicolumn{2}{c}{ Ages 18-64 } & & \multicolumn{2}{c}{ Ages 65+ } \\
\cline { 2 - 3 } \cline { 6 - 7 } & Canada & U.S. & & Canada & U.S. \\
& & & & & & \\
Rate the quality of health care received & & & & & \\
$\quad$ Excellent & 37.7 & 40.4 & & 45.8 & 49.6 \\
$\quad$ Good & 46.7 & 47.5 & & 43.8 & 41.8 \\
$\quad$ Fair & 12.9 & 10.0 & & 8.3 & 6.6 \\
$\quad$ Poor & 2.8 & 2.1 & & 2.1 & 2.1 \\
Satisfaction with health care services & & & & & \\
$\quad$ Very satisfied & 41.5 & 51.3 & & 55.4 & 63.8 \\
$\quad$ Somewhat satisfied & 44.8 & 38.2 & & 35.4 & 28.8 \\
$\quad$ Neither satisfied nor dissatisfied & 5.3 & 3.7 & & 3.1 & 2.2 \\
Somewhat or very dissatisfied & 8.5 & 6.8 & & 6.1 & 5.3 \\
\hline
\end{tabular}

Source: Joint Canada/United States Survey of Health. 


\section{Appendix Table 1}

Means of Characteristics Use in HUI Regressions *

\begin{tabular}{|c|c|c|c|c|}
\hline & \multicolumn{2}{|c|}{ Ages 18-64 } & \multicolumn{2}{|c|}{ Ages 65+ } \\
\hline & Canada & U.S. & Canada & U.S. \\
\hline Household income (in thousands) & 52.459 & 54.506 & 26.250 & 27.607 \\
\hline Household income missing $(0,1)$ & 0.132 & 0.183 & 0.223 & 0.329 \\
\hline Female $(0,1)$ & 0.499 & 0.512 & 0.559 & 0.574 \\
\hline \multicolumn{5}{|l|}{ Age groups: } \\
\hline $18-29(0,1)$ & 0.259 & 0.237 & --- & --- \\
\hline $30-44(0,1)$ & 0.363 & 0.388 & --- & --- \\
\hline $45-64(0,1)$ & 0.378 & 0.375 & --- & --- \\
\hline $65-74(0,1)$ & --- & --- & 0.594 & 0.589 \\
\hline Less than high school $(0,1)$ & 0.145 & 0.095 & 0.452 & 0.207 \\
\hline High school graduate $(0,1)$ & 0.318 & 0.371 & 0.266 & 0.387 \\
\hline Attended community college or vocation school $(0,1)$ & 0.231 & 0.142 & 0.138 & 0.134 \\
\hline Attended university or college $(0,1)$ & 0.307 & 0.392 & 0.144 & 0.272 \\
\hline Non-white $(0,1)$ & 0.187 & 0.264 & 0.131 & 0.157 \\
\hline Immigrant $(0,1)$ & 0.186 & 0.171 & 0.264 & 0.106 \\
\hline Married $(0,1)$ & 0.662 & 0.644 & 0.615 & 0.606 \\
\hline Live alone $(0,1)$ & 0.115 & 0.203 & 0.286 & 0.332 \\
\hline Underweight $(0,1)$ & 0.028 & 0.022 & 0.024 & 0.020 \\
\hline Overweight $(0,1)$ & 0.320 & 0.321 & 0.384 & 0.359 \\
\hline Obese $(0,1)$ & 0.151 & 0.201 & 0.146 & 0.203 \\
\hline Body Mass Index missing $(0,1)$ & 0.035 & 0.039 & 0.026 & 0.035 \\
\hline Daily smoker $(0,1)$ & 0.203 & 0.184 & 0.102 & 0.068 \\
\hline Former daily smokers $(0,1)$ & 0.307 & 0.237 & 0.413 & 0.439 \\
\hline Has asthma $(0,1)$ & 0.066 & 0.077 & 0.069 & 0.060 \\
\hline Has arthritis (excluding fibromyalgia) $(0,1)$ & 0.116 & 0.123 & 0.394 & 0.459 \\
\hline Has high blood pressure $(0,1)$ & 0.087 & 0.130 & 0.405 & 0.452 \\
\hline Has emphysema $(0,1)$ & 0.005 & 0.012 & 0.041 & 0.044 \\
\hline Has diabetes $(0,1)$ & 0.032 & 0.048 & 0.127 & 0.157 \\
\hline Has heart disease $(0,1)$ & 0.024 & 0.023 & 0.133 & 0.167 \\
\hline Has coronary heart disease $(0,1)$ & 0.008 & 0.008 & 0.053 & 0.063 \\
\hline Has angina $(0,1)$ & 0.009 & 0.011 & 0.101 & 0.050 \\
\hline Has major depression $(0,1)$ & 0.089 & 0.096 & 0.033 & 0.033 \\
\hline Has regular medical doctor $(0,1)$ & 0.826 & 0.771 & 0.964 & 0.929 \\
\hline Needed medicines but could not afford it $(0,1)$ & 0.055 & 0.100 & 0.015 & 0.079 \\
\hline \multicolumn{5}{|l|}{ Unmet health need due to: } \\
\hline Long wait or not available $(0,1)$ & 0.063 & 0.018 & 0.036 & 0.017 \\
\hline Cost $(0,1)$ & 0.009 & 0.077 & 0.001 & 0.022 \\
\hline Other reasons $(0,1)$ & 0.042 & 0.046 & 0.032 & 0.025 \\
\hline
\end{tabular}

* All variables are weighted.

Source: JCUSH microdata file. 
Appendix Table 2

Determinants of Health Status As Measured By Health Utility Index (HUI): Partial Regression Coefficients

Intercept

Household income (in thousands)

Household income missing $(0,1)$

Female $(0,1)$

Age groups:

$18-29(0,1)$

45-64 $(0,1)$

$65-74(0,1)$

Less than high school $(0,1)$

Attended comm. col./voc. $(0,1)$

Attended univ. col. $(0,1)$

Non-white $(0,1)$

Immigrant $(0,1)$

Married $(0,1)$

Live alone $(0,1)$

Underweight $(0,1)$

Overweight $(0,1)$

Obese $(0,1)$

Body Mass Index missing $(0,1)$

Daily smoker $(0,1)$

Former daily smokers $(0,1)$

Has asthma $(0,1)$

Has arthritis $(0,1)$

Has high blood pressure $(0,1)$

Has emphysema $(0,1)$

Has diabetes $(0,1)$

Has heart disease $(0,1)$

Has coronary heart disease $(0,1)$

Has angina $(0,1)$

Has major depression $(0,1)$

Has regular medical doctor $(0,1)$

Needed med. couldn't afford $(0,1)$

Unmet health need due to:

Long wait or not available $(0,1)$

Cost $(0,1)$

Other reasons $(0,1)$
Ages 18-64

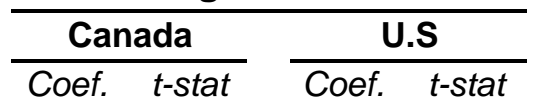

$0.933 \quad 65.19$

$0.000 \quad 4.79$

$0.012 \quad 1.11$

$0.001 \quad 0.23$

$0.018 \quad 2.17$

$0.002 \quad 0.31$

$-0.036-3.80$

$\begin{array}{lll}0.000 & 0.02\end{array}$

$0.008 \quad 1.01$

$-0.001-0.11$

$-0.015-1.72$

$0.023 \quad 2.85$

$\begin{array}{ll}-0.009 & -0.77\end{array}$

$-0.029-1.58$

$-0.013-1.81$

$-0.013 \quad-1.46$

0.0110 .66

0.93177 .18

0.000

0.019

0.006

5.06

2.26

1.04

$\begin{array}{rr}0.010 & 1.29\end{array}$

$-0.020$

$-3.12$

$-0.058 \quad-5.86$

$\begin{array}{ll}0.000 & 0.03\end{array}$

0.018

2.70

$-0.002$

0.003

$-0.33$

0.009

0.39

$-0.004 \quad-0.51$

$\begin{array}{ll}-0.027 & -1.44\end{array}$

$-0.007 \quad-1.06$

$-0.020 \quad-2.57$

$\begin{array}{ll}-0.004 & -0.29\end{array}$

$\begin{array}{ll}-0.022 & -2.64\end{array}$

$-0.013 \quad-1.72$

$\begin{array}{ll}-0.009 & -1.28\end{array}$

$-0.01$

$\begin{array}{ll}-0.051 & -4.18\end{array}$

$\begin{array}{ll}-0.030 & -2.98\end{array}$

$-0.115-11.77$

$-0.112-12.74$

$-0.030 \quad-2.71$

$\begin{array}{ll}-0.021 & -2.35\end{array}$

$\begin{array}{ll}-0.030 & -0.68\end{array}$

$\begin{array}{ll}-0.012 & -0.72\end{array}$

$\begin{array}{ll}-0.021 & -0.94\end{array}$

$\begin{array}{ll}-0.021 & -0.58\end{array}$

$\begin{array}{ll}-0.081 & -2.36\end{array}$

$-0.137-12.58$

$\begin{array}{ll}-0.019 & -2.34\end{array}$

$-0.076-5.53$

$-0.106$

$-0.046$

$-4.28$

$-0.040 \quad-1.93$

$-0.063 \quad-1.84$

$-0.055-1.95$

$-0.151-15.86$

$\begin{array}{ll}-0.097 & -7.89\end{array}$

$-0.043 \quad-1.37$

$\begin{array}{ll}-0.079 & -5.25\end{array}$

$-0.010 \quad-1.50$

$\begin{array}{ll}-0.081 & -7.94\end{array}$

$\begin{array}{ll}-0.028 & -1.38\end{array}$

$-0.058 \quad-5.20$

$\begin{array}{ll}-0.089 & -6.88\end{array}$

Ages 65+
$\frac{\text { Canada }}{\text { Coef. t-stat }}$

0.72811 .55

$0.746 \quad 19.15$

$\begin{array}{lll}0.000 & 0.62\end{array}$

$0.008 \quad 0.31$

$0.001 \quad 0.05$

0.000

1.59

0.014

0.73

$0.032 \quad 1.88$

$\begin{array}{rrrr}0.082 & 4.29 & 0.061 & 3.96 \\ -0.037 & -1.65 & -0.087 & -4.27 \\ -0.007 & -0.24 & 0.010 & 0.44 \\ 0.020 & 0.68 & 0.038 & 2.01 \\ -0.035 & -1.28 & 0.004 & 0.18 \\ -0.053 & -2.51 & 0.003 & 0.12 \\ 0.073 & 2.49 & 0.073 & 3.56 \\ 0.105 & 3.40 & 0.074 & 3.72\end{array}$

$\begin{array}{lll}0.038 & 0.63\end{array}$

$\begin{array}{ll}-0.164 & -3.10\end{array}$

$\begin{array}{lll}0.000 & -0.02\end{array}$

$0.047 \quad 2.71$

$\begin{array}{ll}-0.020 & -0.71\end{array}$

$-0.019 \quad-0.90$

$\begin{array}{ll}-0.009 & -0.15\end{array}$

$-0.056-1.38$

$-0.052-1.63$

$\begin{array}{ll}-0.004 & -0.12\end{array}$

$\begin{array}{ll}-0.006 & -0.28\end{array}$

$\begin{array}{ll}-0.001 & -0.05\end{array}$

$-0.044 \quad-1.20$

$\begin{array}{ll}-0.006 & -0.19\end{array}$

$-0.116-6.14$

$-0.113$

$-0.013$

$-0.045$

$-0.099$

$-0.068$

$-0.060$

0.008

$-0.190$

$-7.38$

$-0.073-1.56$

$-0.060-2.10$

$-0.012-0.36$

$\begin{array}{ll}0.046 & 0.94\end{array}$

$\begin{array}{ll}-0.168 & -4.95\end{array}$

$-0.183-3.50$

$\begin{array}{ll}0.006 & 0.22\end{array}$

$0.070 \quad 1.45$

$\begin{array}{ll}-0.042 & -0.56\end{array}$

$\begin{array}{ll}-0.059 & -2.01\end{array}$

$-0.068 \quad-1.38$

$-0.025 \quad-0.45$

$-0.438-1.12$

$\begin{array}{ll}-0.170 & -3.24\end{array}$

$-0.178 \quad-3.37$

$\begin{array}{lll}-0.204 & -4.32\end{array}$
0.2826

0.7830

1017

Adj. R-Square
Dependent mean

0.2749

0.3143

0.8840

3797

0.2240
684

* Regressions are weighted.

Source: JCUSH microdata file. 